\title{
Equilibrium solubility study to determine fexofenadine hydrochloride BCS class and challenges in establishing conditions for dissolution profiles applied to suspension
}

\author{
Lorena de Sousa Rosa ${ }^{1}$, Flávia Dias Marques-Marinho', \\ Silmara Leôncio Braga², Jacqueline de Souza ${ }^{\circledR * 1}$ \\ 'Programa de Pós-Graduação em Ciências Farmacêuticas da Universidade Federal de \\ Ouro Preto, Campus Morro do Cruzeiro, Minas Gerais, Brasil, ${ }^{2}$ Escola de Farmácia, \\ Universidade Federal de Ouro Preto, Campus Morro do Cruzeiro, Minas Gerais, Brasil
}

\begin{abstract}
The aim of this work was to perform solubility studies for fexofenadine hydrochloride and establish dissolution conditions for this drug in oral suspension dosage form. The solubility study was executed through the shake-flask method, below $37{ }^{\circ} \mathrm{C} \pm 1{ }^{\circ} \mathrm{C}$, at $100 \mathrm{rpm}$ stirring for $12 \mathrm{~h}$ in three buffer solutions: hydrochloric acid $\mathrm{pH} 2.0$, acetate $\mathrm{pH} 4.5$ and phosphate $\mathrm{pH} 6.8$. The dissolution test was developed in vessels containing $900 \mathrm{~mL}$ of the same buffer, employing the paddle apparatus in speed of 25 and $50 \mathrm{rpm}$, below $37{ }^{\circ} \mathrm{C} \pm 0.5^{\circ} \mathrm{C}$. The drug was classified as low solubility according to the Biopharmaceutics Classification System, since the dose/solubility ratio was higher than $250 \mathrm{~mL}$ in all media tested $(326.55 \mathrm{~mL}$ in buffer $\mathrm{pH} 2.0 ; 2,456.33 \mathrm{~mL}$ in buffer $\mathrm{pH} 4.5$ and $1,021.16 \mathrm{~mL}$ in buffer $\mathrm{pH}$ 6.8 ). The dissolution test showed that a release of $85 \%$ in $30 \mathrm{~min}$ could be established. The rotation speed of $25 \mathrm{rpm}$, media volume of $900 \mathrm{~mL}$ and insertion of the samples through weighted syringes are adequate. The buffered media $\mathrm{pH} 2.0$ could be chosen as dissolution media.
\end{abstract}

Keywords: Fexofenadine hydrochloride. HPLC method. Biopharmaceutics. Suspension. Dissolution profile.

\section{INTRODUCTION}

Fexofenadine hydrochloride (FEX HCl) (Figure 1) is an inverse agonist of peripheral histaminic receptors H-1 (Simons, Simons, . It shows systemic distribution, but it does not cross the blood-brain barrier, and therefore does not induce sedation (Fromm, 2004). It is a zwitterion produced as racemic mixture (Aventis, 2006).
*Correspondence: J. de Souza, Programa de Pós-Graduação em Ciências Farmacêticas, Universidade Federal de Ouro Preto, Campus Morro do Cruzeiro, Minas Gerais, Brasil. Zipcode: 35400 000. e-mail: jacsouza@ ufop.edu.br and desouzajacque08@gmail.com

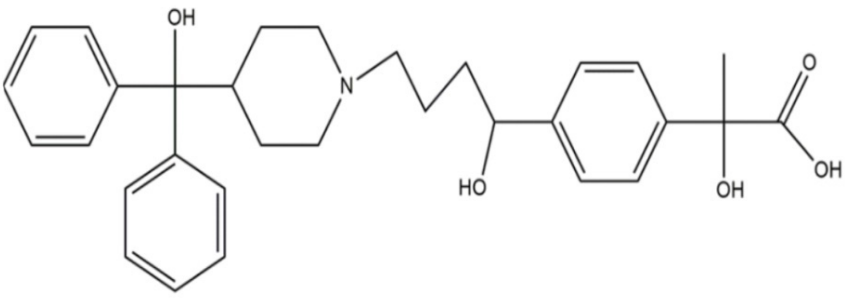

FIGURE 1 - Chemical structure of fexofenadine.

The drug has low aqueous solubility (Brasil 2010) which allows its manufacturing as an oral suspension. This dosage form is characterized for having two phases where the insoluble solid phase is dispersed in the liquid phase. When the objective is the quality control of the drugs administered in insoluble forms, the dissolution 
study is requested (Brasil, 2011). Notwithstanding there are few recommendations of oral suspension dissolution procedures in the official compendia (Brasil, 2010; United States, 2013). In spite of having low solubility, it was recently shown that $\mathrm{FEX} \mathrm{HCl}$ can be formulated as an orally disintegrated tablet for pediatric use. In this dosage form the dissolution was considered very fast (Türkmen, Ay Şenyiğit, Baloğlu, 2018). On, the other hand the drug dissolution is an auxiliary tool in the Biopharmaceutics Classification System, which evaluates the drug according its solubility and permeability (Amidon et al., 1995) and suggests one of the four classes: I - high solubility/ permeability, II - low solubility/high permeability, III high solubility/low permeability and IV - low solubility/ permeability. The dissolution study is applied to verify the interference of excipients in drug release (Amidon et al., 1995).

Although there are publications that develop dissolution methods for tablets and capsules comparing the performance of different apparatus, stirring rate, volumes and constitution of media (Breier et al., 2005; Oliveira, Weich, Rolim, 2007), one of our aims was to understand challenges in developing dissolution methods for oral suspensions dosage form. The second aim was to apply BCS approach to dissolution profile in vitro conditions that make it possible to preview differences in drug dissolution in vivo. Our contribution is to discuss relevant aspects that must be evaluated when testing suspensions. FEX $\mathrm{HCl}$ here was our model drug for its low solubility. Since the focus of this work is the study of the suspension oral liquid dosage form, studies about solid oral dosage forms, such as capsules and tablets, which are already well established, will not be discussed here.

This paper aims to highlight the biopharmaceutical characteristic of solubility for $\mathrm{FEX} \mathrm{HCl}$ and develop a dissolution test for the oral suspension. This is essential information for the prediction of drug behavior in vivo, for monitoring product quality as well as for the development of generic medicines. This is an innovative work in this field considering the absence of similar experiments with FEX $\mathrm{HCl}$.

\section{MATERIAL AND METHODS}

\section{Material}

FEX $\mathrm{HCl}$ active pharmaceutical ingredient (CHIZOU, China) was purchased in Brazilian market, the Brazilian Pharmacopea standard reference substance was kindly provided by FIOCRUZ and the oral pediatric suspension (Allegra Pediátrico ${ }^{\circledR}$, Sanofi Aventis, Brazil) was acquired in the local market. Acetonitrile (MerckLiChrosoh ${ }^{\circledR}$, Germany) and methanol (JT Baker, Mexico) were purchased with chromatographic purity. Ultrapure water obtained from the DirectQ (Millipore, USA) was used. For the chromatographic analysis a C18 Zorbax Eclipse ${ }^{\circledR}, 150 \times 4.6 \mathrm{~mm}, 5 \mu \mathrm{m}$ column (Agilent, USA) and a high performance liquid chromatography with diode array detector 2695 (Waters, Milliford, USA) were employed.

The solubility study was performed in the Shaker incubator KS 40000i Control (IKA, Germany). The oral suspension was characterized employing the rotational viscometer (Viscotester, ThermoScientific, USA) and Zetasizer PN 3072 (England). The dissolution test was developed in automatic dissolutor Vision ${ }^{\circledR}$ G2 Elite 8/ AutoPlus \& Autofill (Hanson, USA).

\section{Chromatographic Method}

The mobile phase was constituted by monobasic phosphate buffer ( $\mathrm{pH} 6.8,25 \mathrm{mM})$ - acetonitrile (68:32, $\mathrm{v} / \mathrm{v})$. The buffer $\mathrm{pH}$ was adjusted with $\mathrm{NaOH}(1.0 \mathrm{M})$ before adding it to the organic solvent. The mobile phase was filtered in a $0.45 \mu \mathrm{m}$ membrane and degassed for $30 \mathrm{~min}$ in ultrasonic bath. Other established conditions were flow rate of $1.0 \mathrm{~mL} \cdot \mathrm{min}^{-1}$, temperature $30^{\circ} \mathrm{C}, 20 \mu \mathrm{L}$ injection and detection at $220 \mathrm{~nm}$.

The validation occurred according parameters established in the ICH Guidelines, in three media: $\mathrm{pH} 2.0$ hydrochloric acid buffer, $\mathrm{pH} 4.5$ acetate buffer and $\mathrm{pH} 6.8$ phosphate buffer (United States, 2013). The analytical curves in the $\mathrm{pH} 2.0$ and $\mathrm{pH} 4.5$ buffers were obtained in the concentrations $15,25,40,55,70,90$ and $110 \mu \mathrm{g} \cdot \mathrm{mL}^{-1}$ and in the interval 15, 25, 40, 55, 70 and $90 \mu \mathrm{g} \cdot \mathrm{mL}^{-1}$ in the pH 6.8 buffer. The curve solutions were prepared from the dilution of the fresh stock standard solution whose concentration was $500 \mu \mathrm{g} \cdot \mathrm{mL}^{-1}$ in methanol. The method was validated according to linearity, precision, accuracy, robustness, quantification and detection limits. Selectivity was performed in triplicate using acid, alkaline and thermal stress conditions. The solutions were prepared at concentrations of $70 \mu \mathrm{g} \cdot \mathrm{mL}^{-1}(\mathrm{ICH}, 1996)$.

\section{Stability and Solubility Studies}

The stability study employed triplicates of FEX HCl solutions at $55 \mu \mathrm{g} \cdot \mathrm{mL}^{-1}$ in each buffer $(\mathrm{n}=9)$ which were prepared from the $525 \mu \mathrm{g} \cdot \mathrm{mL}^{-1}$ stock standard solution 
Equilibrium solubility study to determine fexofenadine hydrochloride BCS class and challenges in establishing conditions for dissolution profiles applied to suspension

in methanol. The solutions were incubated in the same conditions established for the solubility measurement. Samples of $1 \mathrm{~mL}$ were collected after 1, 3, 6, 9 and $12 \mathrm{~h}$, filtered in $0.45 \mu \mathrm{m}$ membrane before analyzed by HPLC. The FEX and possible degradation peaks were checked. Stability was evaluated by the relative standard deviation of concentrations for each time.

The solubility of FEX $\mathrm{HCl}$ (active pharmaceutical ingredient) was evaluated in triplicate using the following media $(100 \mathrm{~mL})$ : $\mathrm{pH} 2.0$ hydrochloric acid solution, $\mathrm{pH} 4.5$ acetate and $\mathrm{pH} 6.8$ phosphate buffers. The amounts of drug were $66 \mathrm{mg}$ of $\mathrm{FEX} \mathrm{HCl}$ in $\mathrm{pH} 2.0$, $8 \mathrm{mg}$ in $\mathrm{pH} 4.5$ and $16 \mathrm{mg}$ in $\mathrm{pH}$ 6.8.The test conditions were at temperature of $37^{\circ} \mathrm{C} \pm 1^{\circ} \mathrm{C}, 100 \mathrm{rpm}$ stirring for $12 \mathrm{~h}$ with sample collection and medium replacement (1 $\mathrm{mL}$ ) at 1, 3, 5, 7, 9 and $12 \mathrm{~h}$. The samples collected from $\mathrm{pH} 2.0$ and $\mathrm{pH} 6.8$ buffers were filtered and afterwards diluted 1:10 and 1:4, respectively in the same medium.

\section{Oral Suspension Characterization}

The oral suspension was characterized according to $\mathrm{pH}$, viscosity, polydispersity index, particle size and zeta potential measurements. Viscosity and $\mathrm{pH}$ were determined in $100 \mathrm{~mL}$ of the shaken oral suspension placed into a beaker. A single drop of the suspension dispersed in $1 \mathrm{~mL}$ of ultrapure water was employed for the other determinations of particles size and zeta potential using Zetasizer PN3702 equipment.

The FEX $\mathrm{HCl}$ content was determined by adding the oral suspension $(5 \mathrm{~mL})$ and methanol $(100 \mathrm{~mL})$ to a $250 \mathrm{~mL}$ volumetric flask $(\mathrm{n}=3)$ followed by sonication for $30 \mathrm{~min}$ to promote extraction. Then, the flask volumes were completed with hydrochloric acid buffer $\mathrm{pH} 2.0$ and sonicated for more $30 \mathrm{~min}$. The solutions were passed through paper filter and $5 \mathrm{~mL}$ of the filtered sample were transferred to a $10 \mathrm{~mL}$ volumetric flask, whose volume was completed with the same buffer. These samples were filtered in $0.45 \mu \mathrm{m}$ membrane before being quantified by HPLC.

In Brazil there is only a single product marked as oral suspension for FEX $\mathrm{HCl}$.

\section{Dissolution Study}

\section{Determination of Sink Condition}

The sink condition was determined in each buffer. The dose of oral suspension used in the dissolution test $(30 \mathrm{mg}$ ) was divided by the solubility in respective medium and the result was multiplied by 3 . This volume was defined as the minimum necessary to maintain sink conditions to the dose.

\section{Dissolution Test}

The dissolution test was performed using paddle apparatus at $25 \mathrm{rpm}$ and $50 \mathrm{rpm}$ in $\mathrm{pH} \mathrm{2.0,4.5}$ and 6.8 buffers maintained at $37^{\circ} \mathrm{C} \pm 0.5^{\circ} \mathrm{C}$ until $45 \mathrm{~min}$. Between $45 \mathrm{~min}$ and $60 \mathrm{~min}$, the paddle rotation was established at $150 \mathrm{rpm}$. The $900 \mathrm{~mL}$ medium volume was defined in order to assure the sink conditions. The samples were inserted using glass syringes which were weighted when empty, filled and unfilled with the suspension. The aliquot withdrawal occurred with medium replacement $(5 \mathrm{~mL})$ at $2,6,10,15,30$, 45 and $60 \mathrm{~min}$. The aliquots were filtered in 0.45 $\mu \mathrm{m}$ membranes before being analyzed by HPLC without dilution

\section{RESULTS AND DISCUSSION}

\section{Analytical Method Validation}

The method was adequate to the purpose of solubility and dissolution studies of $\mathrm{FEX} \mathrm{HCl}$, showing selectivity, linearity, precision and accuracy according to the ICH guidelines. Figure 2 shows the method selectivity after 24 hours $\left(96{ }^{\circ} \mathrm{C}\right)$ for thermal stress, and $1 \mathrm{~h}$ for alkaline and acid stresses. The peak purity indicated the main peak was free of interferences, since the purity angle is smaller than the threshold angle.

The method was linear in the range from 15 to $110 \mu \mathrm{g} . \mathrm{mL}^{-1}$ to FEX solutions diluted in the $\mathrm{pH} 2.0$ and 4.5 buffers, and from 15 to $90 \mu \mathrm{g} . \mathrm{mL}^{-1}$ to FEX solutions diluted in the buffer $\mathrm{pH} 6.8$ with correlation coefficient (R) values higher than 0.99 (Table I) Quantification and detection limits (Table I) were calculated (ICH, 1996). On the other hand the R2 indicates that the linearity data have high correlation, since it is the coefficient of determination (Kenneth, 2001). The relative standard deviation was lower than $5 \%$ for the lower, middle and higher concentrations, as requested in the law (ICH 1996).The accuracy was observed when the method was used to quantify a substance of known purity, the fexofenadine hydrochloride reference substance. The values ranged from 98 to $103 \%$, and that is considered adequate for accuracy in pharmaceutical products, where 
the values may be placed between 95 and 105\% (Rozet et al., 2007). This method was also precise in quantifying fexofenadine hydrochloride in low, intermediate and higher concentrations, as the RSD was lower than 5\% (Table II).

The method was robust in most of conditions tested, except when changing the temperature to $29^{\circ} \mathrm{C}$
(RSD 2.36\%) and the mobile phase proportion to 70:30 (phosphate buffer: acetonitrile)(RSD 2.18\%), which affected the results when $\mathrm{FEX} \mathrm{HCl}$ is diluted in the $\mathrm{pH}$ 6.8 phosphate buffer. The variability for other media used was not higher than $2 \%$ (Table III).

a)

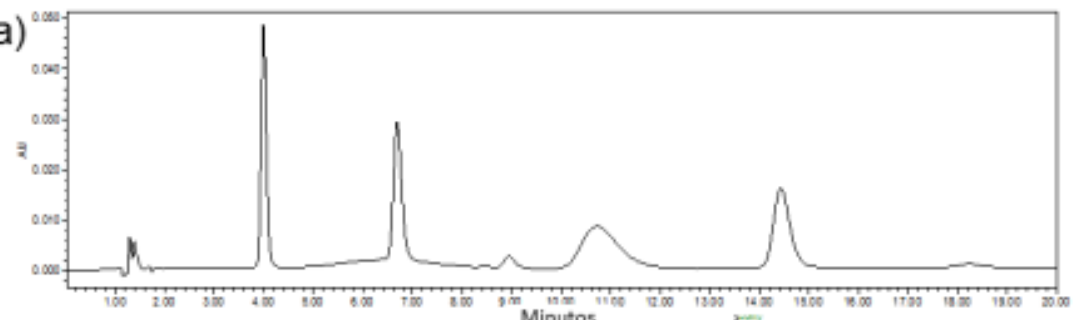

b)
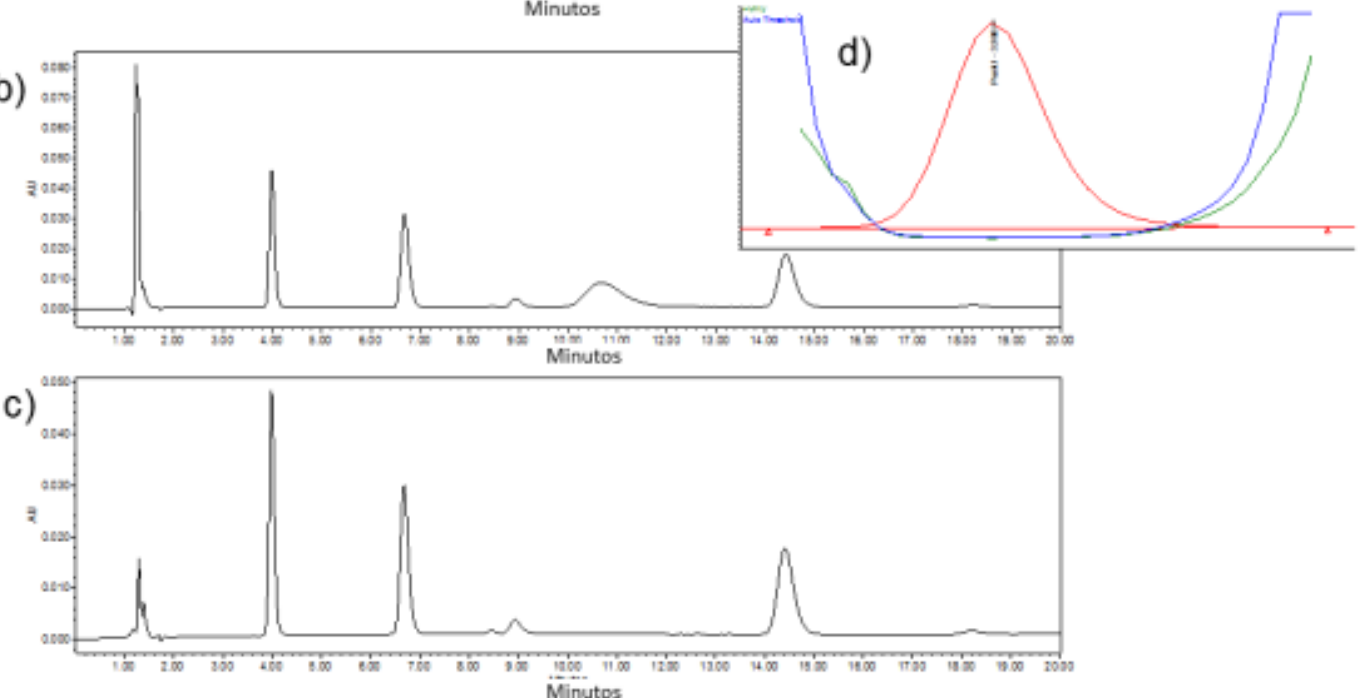

FIGURE 2 - Chromatographic specter after acid stress of FEX HCl. A, b and c are the triplicates. D shows the substance was pure.

TABLE I - Chromatogram of FEX HCl after acid stress and dilution in (a) $\mathrm{pH}$ 2, (b) $\mathrm{pH} 4.5$ and (c) pH 6.8 buffers; (d) FEX HCl UV purity spectrum'

\begin{tabular}{lccc}
\hline Data & $\mathbf{p H ~ 2 . 0}$ & $\mathbf{p H ~ 4 . 5}$ & $\mathbf{p H ~ 6 . 8}$ \\
\hline $\mathrm{R}^{2}$ & 0.999 & 0.997 & 0.999 \\
$\mathrm{R}$ & 0.999 & 0.999 & 0.999 \\
Intercept & -86459 & -120735 & -31583 \\
Curve RSD & 1.82 & 3.29 & 2.14 \\
p-value** & 0.28 & 0.44 & 0.70 \\
Detection & 3.83 & 1.55 & 1.79 \\
Quantification & 12.77 & 5.16 & 5.93 \\
\hline
\end{tabular}

**If p-value is higher than 0.05 , the intercept is not different from zero and data are homogenous. 
Equilibrium solubility study to determine fexofenadine hydrochloride BCS class and challenges in establishing conditions for dissolution profiles applied to suspension

TABLE II - Results obtained for precision and accuracy during method validation

\begin{tabular}{lccc}
\hline Buffer $\mathbf{p H}$ & Concentration $\left(\boldsymbol{\mu g . \mathbf { m L } ^ { - 1 } )}\right.$ & Precision $(\mathbf{\% R S D})$ & Accuracy $(\mathbf{\%})$ \\
\hline \multirow{4}{*}{15} & 2.43 & 103.52 \\
& 55 & 2.44 & 100.95 \\
& 110 & 2.10 & 100.36 \\
4.5 & 15 & 2.71 & 102.62 \\
& 55 & 1.83 & 100.02 \\
6.8 & 110 & 1.90 & 100.80 \\
& 15 & 2.65 & 102.97 \\
& 55 & 2.10 & 98.83 \\
\hline
\end{tabular}

TABLE III - Robustness of the validated chromatographic method

\begin{tabular}{lcccc}
\hline Parameters (units) & Variations & \multicolumn{3}{c}{ Buffer (pH) \%RSD } \\
\hline & & 2.0 & 4.5 & 6.8 \\
& 29 & 0.5 & 1.3 & 2.3 \\
$\mathrm{~T}\left({ }^{\circ} \mathrm{C}\right)$ & 31 & 0.2 & 1.1 & 1.8 \\
& 0.9 & 0.2 & 1.4 & 1.5 \\
Flow (mL.min $\left.{ }^{-1}\right)$ & 1.1 & 0.3 & 1.0 & 1.2 \\
& 34 & 0.7 & 1.3 & 1.8 \\
Acetonitrile (\%) & 30 & 0.2 & 1.1 & 2.1 \\
& & & 1.4 & 1.6 \\
Mobile phase (pH) & 6.7 & 0.5 & 1.0 & 1.6 \\
\hline
\end{tabular}

\section{Stability and Solubility Studies}

The stability study performed showed that FEX $\mathrm{HCl}$ is stable in all three media used, since variations in concentrations in $12 \mathrm{~h}$ were so low that the results would not be affected by the time of analysis (Table IV).

Solubility is defined in the calculation of dose/ solubility ratio, which should be lower than $250 \mathrm{~mL}$ to indicate high solubility of a drug. The dose can be defined as the highest commercial strength available (FDA, 2015) or as the highest dose orally (EMA, 2010). The dose (D) employed was $30 \mathrm{mg}$, the highest dose for the suspension. The solubility data, however, was the highest value achieved in the test, obtained after the establishment of the balance between the two phases in suspension, the aqueous buffer and the drug particles. The solubility value used is the one where the highest concentration is found until the equilibrium 
is established and the values were measured as 551.21 $\mu \mathrm{g} . \mathrm{mL}^{-1}$ (pH 2.0), $73.28 \mu \mathrm{g} \cdot \mathrm{mL}^{-1}$ (pH 4.5) and 176.27 $\mu \mathrm{g} \cdot \mathrm{mL}^{-1}$ (pH 6.8). The study shows that FEX HCl is a low solubility drug (Figure 3 ), since the results for $\mathrm{D} / \mathrm{S}$ were $326.55 \mathrm{~mL}$ in $\mathrm{pH} 2.0,2,456.33 \mathrm{~mL}$ in $\mathrm{pH} 4.5$ and $1,021.16$ in $\mathrm{pH}$ 6.8. Considering the maximum dose, which is $30 \mathrm{mg}$ for $\mathrm{FEX} \mathrm{HCl}$ in oral suspension, the results change to $54.42 \mathrm{~mL}, 409.39 \mathrm{~mL}$ and $170.19 \mathrm{~mL}$ in $\mathrm{pH} 2.0,4.5$ and 6.8 , respectively, which characterizes the drug as having $\mathrm{pH}$-dependent solubility. These buffers were chosen because they mimic the physiological $\mathrm{pH}$ in the gastrointestinal tract, and are recommended by the regulatory agencies (EMA, 2010; FDA, 2015).
TABLE IV - Relative standard deviation of concentrations of $\mathrm{FEX} \mathrm{HCl}$ solutions evaluated in stability for each buffer between triplicates

\begin{tabular}{lccc}
\hline & \multicolumn{3}{c}{ \%RSD FEX HCl } \\
\hline $\begin{array}{l}\text { Time } \\
\text { (h) }\end{array}$ & pH 2.0 & pH 4.5 & pH 6.8 \\
\hline 0 & 1.51 & 1.98 & 3.37 \\
1 & 1.37 & 1.43 & 2.85 \\
3 & 0.87 & 0.66 & 3.71 \\
6 & 1.30 & 1.53 & 2.19 \\
9 & 1.68 & 0.73 & 2.18 \\
12 & 0.97 & 1.14 & 1.98 \\
\hline
\end{tabular}

\section{a)}

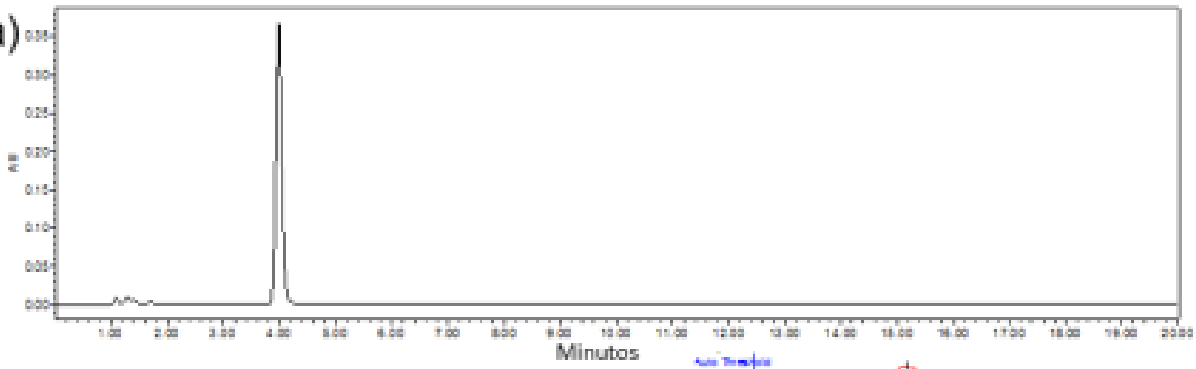

b)
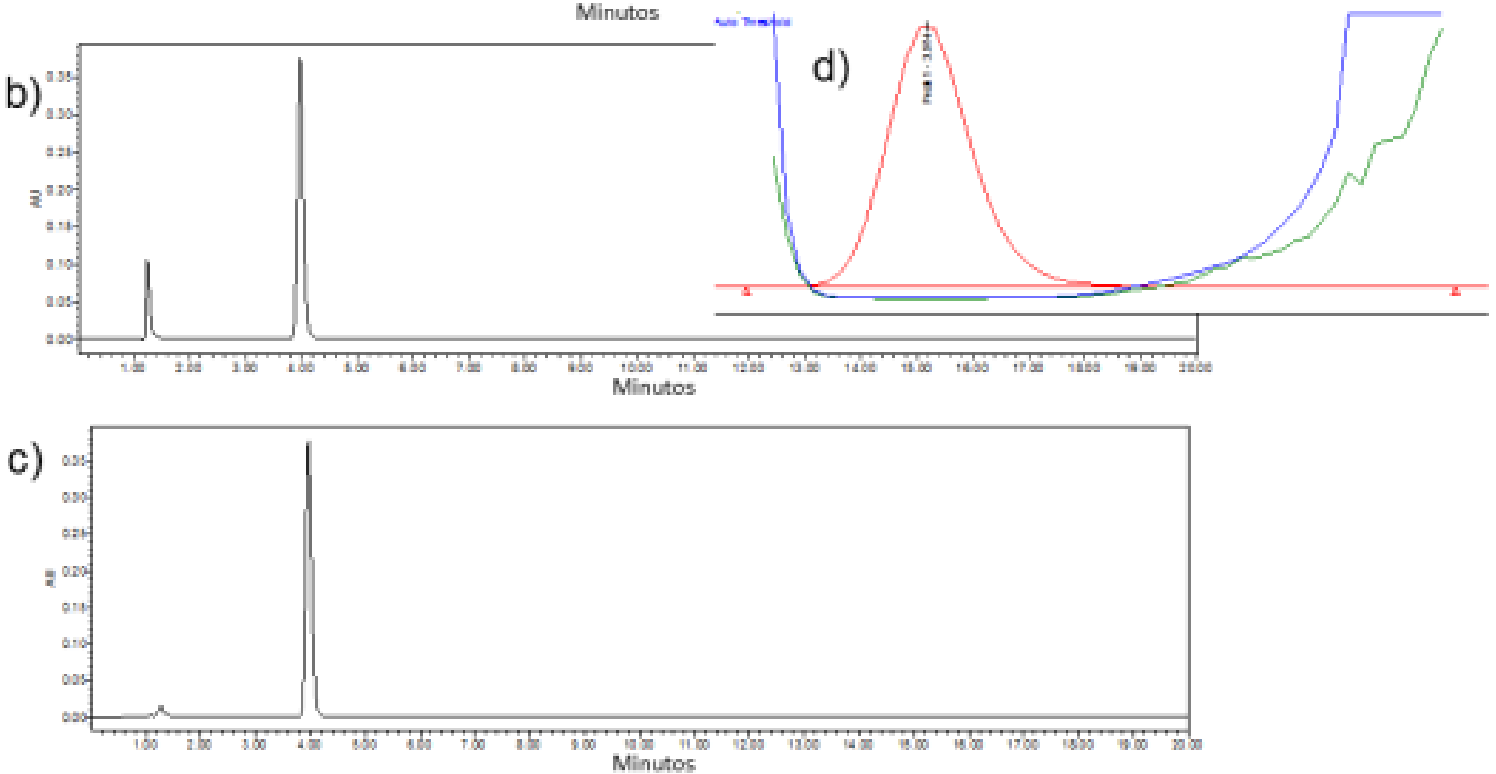

FIGURE 3 - Chromatogram of FEX HCl after alkaline stress and dilution in (a) $\mathrm{pH}$ 2, (b) $\mathrm{pH} 4.5$, (c) $\mathrm{pH} 6.8$ buffers and (d) FEX $\mathrm{HCl}$ UV purity spectrum.' 


\section{Dissolution Study}

The oral suspension purchased at the local market presented a $\mathrm{pH} 6.25$ and viscosity of $135 \mathrm{mPa}$. The average size of the dispersed particles was $795.10 \mathrm{~nm}(\mathrm{n}=3, \% \mathrm{RSD}$ 1.66), the polydispersity index was $0.36(\mathrm{n}=3, \% \mathrm{RSD}$ 4.6) and zeta potential was $-36.70 \mathrm{mV}$ ( $\mathrm{n}=3, \% \mathrm{RSD} 2.4)$. These results indicate that the suspension has particles homogeneously distributed in size, has low viscosity comparatively to other medicines as suspension dosage form and is highly stable. The physical-chemical studies of suspensions show that smaller particles will exhibit a better profile in solubility and dissolution studies. Nanosized, micronized particles have facilitated diffusion in the solvent. Reducing particle sizes is a very practical method to increase the solubility of poor soluble drugs (Gowthamarajan, Singh, 2010).

A zeta potential different from the interval ranging $\pm 30 \mathrm{mV}$ suggests high stability, and values of polydispersity index close to zero demonstrate low variability in particle size. Both reflect stability and are related to the probability of sedimentation for the suspension, since the larger particles precipitate faster and the increase in zeta potential leads to higher repulsion between particles which cause their precipitation (Carstensen, Stremming, Pothisiri, 1972). The evaluation of the raw powder was not fulfilled.
The excipients found in the oral suspension were propylene glycol, disodium edetate, propylparaben, diethylparaben, xantham gum, poloxamer, titanium dioxyde, monobasic sodium phosphate, dibase sodium phosphate, sucrose and xylitol. The oral suspension content was measured using the buffer $\mathrm{pH} 2.0$ as diluent due to the higher solubility in this solution. In the absence of official monography for FEX $\mathrm{HCl}$ oral suspension, the limit value established was from 90.0 to $110.0 \%$, value cited in Brazilian pharmacopeia for fexofenadine hydrochloride tablets, and the results were $108.5 \%, 107.3 \%$ and $106.3 \%$ for each replicate. The use of buffered media in the physiological $\mathrm{pH}$ range representing portions of the TGI is important in proposing the in vitro conditions that enable better predictability of the in vivo behavior of the drug (FDA, 2015). Sink condition was calculated for each buffer solution and it defines the volume of media needed to dissolve (3 times) the dose of the dosage form utilized. Results were $175.58 \mathrm{~mL}, 1,228.16 \mathrm{~mL}$ and $510.58 \mathrm{~mL}$ for $\mathrm{pH} 2.0,4.5$ and 6.8 buffers respectively. In face of that, the sink condition is not accomplished for buffer $\mathrm{pH} 4.5$ since the dissolution should be performed in $900 \mathrm{~mL}$ vessels.

In the dissolution test the sample insertion method had huge effects on the conditions tested and the rotation speed of $25 \mathrm{rpm}$ (Figure 4) generated

a)

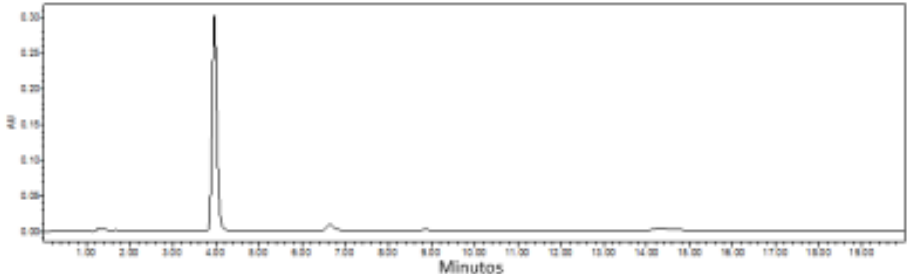

b)

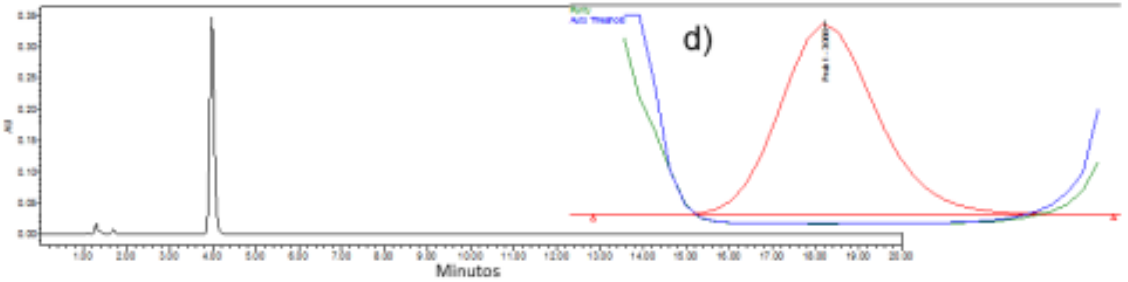

c)

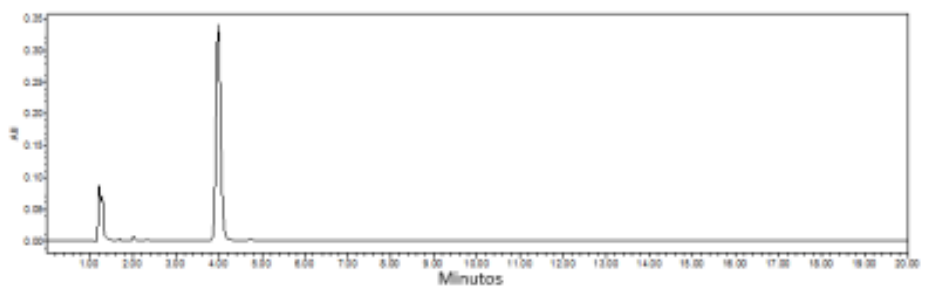

FIGURE 4 - Chromatogram of FEX HCl after thermic stress and dilution in (a) pH 2, (b) pH 4.5, (c) pH 6.8 buffers and (d) FEX HCl UV purity spectrum.' 
more consistent profiles. This finding was observed in another work (Soares, 2016) developed in our laboratory, which tested variation in the insertion method through unloading the syringe in the central point or border of the vessels, and weighting or not the syringe. In that work smaller variation of dissolution results were found when inserting the sample by weighing the syringe before and after. Based on this previous observation, the difficulty was mentioned, but not tested in this study. There were discrepancies in the quantities dissolved in each time between the vessels and it was an impediment to calculate the dissolution efficiency for all the conditions, since some reached $85 \%$ release before $30 \mathrm{~min}$. When the rotation speed of $50 \mathrm{rpm}$ was used (Figure 5) the dissolution was considered very fast, $85 \%$ of the drug dissolved within $15 \mathrm{~min}$. This is probably due to the particles of small size composing the oral suspension, which also showed great homogeneity. Under these conditions the procedure makes the test less discriminatory. Table $\mathrm{V}$ presents statistical data for the dissolution test in both rotation speeds and for the different $\mathrm{pH}$ solutions used. It shows that the variability between the vessels are enormous, although the process becomes homogeneous before $30 \mathrm{~min}$ of dissolution.

It was observed that in the $\mathrm{pH} 6.8$ buffer, the dissolution did not achieve $85 \%$ within 30 min in all vessels, thus it is not a good condition (Figures 3 and 4). For the other buffers, a fast dissolution was verified, $85 \%$ of the drug dissolved within $30 \mathrm{~min}$. Nevertheless, the sink conditions are not reached in $\mathrm{pH} 4$.5. From these results, the $\mathrm{pH} 2.0$ buffer seems to be adequate for the dissolution test. The dissolution test, when developed to quality control, must be robust and discriminative in order to identify batches with problems. Different media, with distinct $\mathrm{pH}$ and variable rotation speeds are recommended (Limberg, Potthast, 2013). However it is also of great importance to know the drug solubility in each medium and the drug dosage form must be considered (Graffner, 2006).

This method could be applied to routine of quality control and for biopharmaceutical purposes. In this field, it was noticed that rate of drug release does not represent a limit step for drug absorption. This fact is related to the smaller sizes of the particles, which improve the solubility speed by the media in

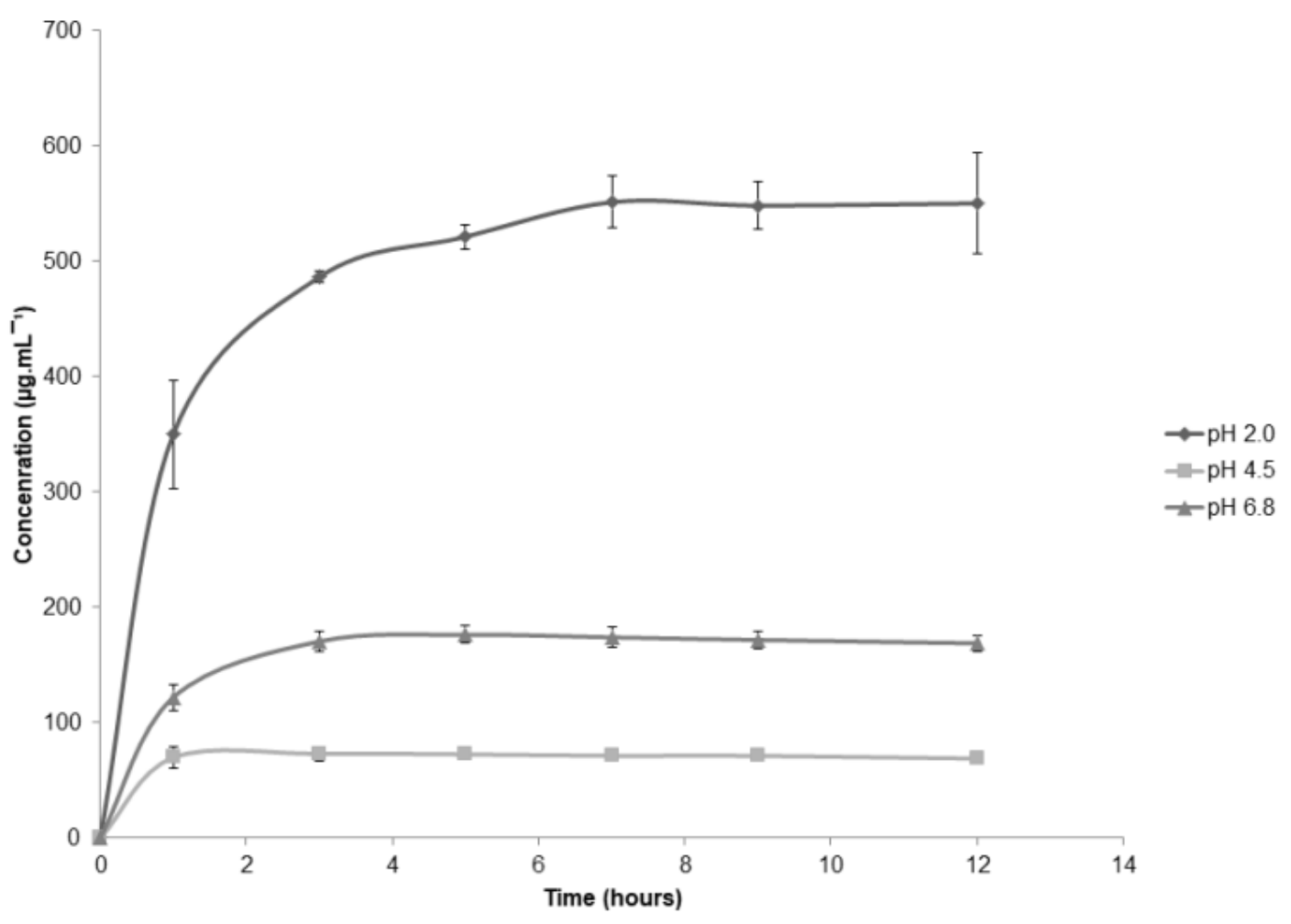

FIGURE 5 - Equilibrium solubility curves of $\mathrm{FEX} \mathrm{HCl}(\mathrm{n}=3)$ in different buffers using shake flask method. 
vivo or in vitro. Among the excipients found in the oral suspension, it is known that poloxamer and propylene glycol increase the dissolution rate (Sruti et al., 2013). For quality control purposes simple aqueous buffers are appropriated, but when it is desirable to predict the drug in vivo behavior, buffers mimicking the physiological conditions that occur in the gastrointestinal tract are preferred. These solutions usually have the $\mathrm{pH}$ ranging from 1.2 to 6.8 (Limberg, Potthast, 2013), representing the environment in the stomach and the small intestine (Avdeef, 2003) and allowing to define if the dissolution from the dosage form is a limiting step for the drug absorption or if the formulation has impact in the drug release (Dressman et al., 1998). At this point, the dissolution is an important step in the biopharmaceutical studies, where solubility and permeability are also factors limiting the absorption of an active pharmaceutical ingredient (Amidon et al., 1995).
Finally, the $\mathrm{pH} 2.0$ buffer offered the best dissolution conditions when paddle apparatus at $25 \mathrm{rpm}$ was used. The criterion is suggested based in release of $85 \%$ within 30 min for $\mathrm{FEX} \mathrm{HCl}$ in oral suspension

\section{FUNDING}

The authors would like to thank the "Fundação de Amparo à Pesquisa do Estado de Minas Gerais" (FAPEMIG), grant number APQ-02247-14, "Rede Mineira de Ensaios Toxicológicos e Farmacológicos da FAPEMIG (Rede TOXIFAR), grant number CBB - RED00008-14, Universidade Federal de Ouro Preto (PROPP/ UFOP) for financial support. This study was financed in part by the Coordenação de Aperfeiçoamento de Pessoal de Nível Superior - Brasil (CAPES) - Finance Code 001 and $\mathrm{CNPq}$ (Conselho Nacional de Desenvolvimento Científico e Tecnológico).

TABLE V - Statistical analysis of the dissolution test in $\mathrm{pH} 2.0,4.5$ and 6.8 using paddle apparatus rotation speed of 25 and $50 \mathrm{rpm}$

\begin{tabular}{|c|c|c|c|c|c|c|}
\hline \multirow{3}{*}{$\begin{array}{l}\text { Time } \\
(\min )\end{array}$} & \multicolumn{6}{|c|}{ FEX HCI \% release (\%RSD) } \\
\hline & \multicolumn{3}{|c|}{25 RPM } & \multicolumn{3}{|c|}{50 RPM } \\
\hline & pH 2.0 & pH 4.5 & pH 6.8 & pH 2.0 & pH 4.5 & pH 6.8 \\
\hline 0 & $\begin{array}{l}0.00 \\
(0.0)\end{array}$ & $\begin{array}{l}0.00 \\
(0.0)\end{array}$ & $\begin{array}{l}0.00 \\
(0.0)\end{array}$ & $\begin{array}{l}0.00 \\
(0.0)\end{array}$ & $\begin{array}{l}0 . .00 \\
(0.0)\end{array}$ & $\begin{array}{l}0.00 \\
(0.0)\end{array}$ \\
\hline 2 & $\begin{array}{c}74.0 \\
(27.3)\end{array}$ & $\begin{array}{c}80.3 \\
(14.6)\end{array}$ & $\begin{array}{l}83.3 \\
(3.0)\end{array}$ & $\begin{array}{c}78.8 \\
(26.4)\end{array}$ & $\begin{array}{c}86.1 \\
(14.6)\end{array}$ & $\begin{array}{c}76.4 \\
(27.2)\end{array}$ \\
\hline 6 & $\begin{array}{c}77.2 \\
(20.8)\end{array}$ & $\begin{array}{c}82.5 \\
(12.1)\end{array}$ & $\begin{array}{l}85.6 \\
(4.4)\end{array}$ & $\begin{array}{c}88.5 \\
(13.4)\end{array}$ & $\begin{array}{l}88.9 \\
(6.7)\end{array}$ & $\begin{array}{l}85.9 \\
(4.3)\end{array}$ \\
\hline 10 & $\begin{array}{c}79.2 \\
(17.9)\end{array}$ & $\begin{array}{c}83.9 \\
(11.2)\end{array}$ & $\begin{array}{l}85.7 \\
(4.2)\end{array}$ & $\begin{array}{l}94.7 \\
(4.1)\end{array}$ & $\begin{array}{l}90.1 \\
(4.4)\end{array}$ & $\begin{array}{l}86.7 \\
(2.7)\end{array}$ \\
\hline 15 & $\begin{array}{c}83.4 \\
(13.4)\end{array}$ & $\begin{array}{l}85.1 \\
(9.1)\end{array}$ & $\begin{array}{l}85.3 \\
(4.3)\end{array}$ & $\begin{array}{l}96.4 \\
(1.8)\end{array}$ & $\begin{array}{l}90.0 \\
(3.1)\end{array}$ & $\begin{array}{l}86.4 \\
(2.4)\end{array}$ \\
\hline 30 & $\begin{array}{c}91.9 \\
(5.24)\end{array}$ & $\begin{array}{l}89.4 \\
(3.3)\end{array}$ & $\begin{array}{l}86.1 \\
(2.8)\end{array}$ & $\begin{array}{l}96.3 \\
(1.9)\end{array}$ & $\begin{array}{l}89.9 \\
(2.9)\end{array}$ & $\begin{array}{l}85.9 \\
(2.5)\end{array}$ \\
\hline 45 & $\begin{array}{l}93.7 \\
(3.0)\end{array}$ & $\begin{array}{l}89.8 \\
(4.4)\end{array}$ & $\begin{array}{l}85.7 \\
(2.7)\end{array}$ & $\begin{array}{l}95.6 \\
(1.9)\end{array}$ & $\begin{array}{l}88.9 \\
(3.0)\end{array}$ & $\begin{array}{l}85.4 \\
(2.2)\end{array}$ \\
\hline 60 & $\begin{array}{l}94.3 \\
(2.5)\end{array}$ & $\begin{array}{l}90.1 \\
(3.6)\end{array}$ & $\begin{array}{l}84.8 \\
(2.7)\end{array}$ & $\begin{array}{l}94.9 \\
(2.2)\end{array}$ & $\begin{array}{l}88.5 \\
(3.1)\end{array}$ & $\begin{array}{l}85.1 \\
(2.1)\end{array}$ \\
\hline
\end{tabular}




\section{REFERENCES}

Amidon GL, Lennernas H, Shah VP, Crison JR. A theoretical basis for a biopharmaceutic drug classification: the correlation of in vitro drug product dissolution and in vivo bioavailability. Pharm Res. 1995;12(3):413-420.

Avdeef, A. Absorption and drug development: solubility, permeability and charge state. United States, John Wiley and Sons. 2003.

Aventis, S. Product Monograph Allegra. West Laval, Quebec. 2006;1.1:24.

Brasil. Farmacopeia Brasileira. Brasília, Agência Nacional de Vigilância Sanitária. 2; 2010. 545p.

Brasil. RDC No 37, DE 3 DE AGOSTO DE 2011. A. N. d. V. Sanitária. Brasil, Ministério da Saúde;2011.13p.

Breier AR, Paim CS, Steppe M, Schapoval EE. Development and validation of dissolution tests for fexofenadine hydrochloride capsules and coated tablets. J Pharm Pharm Sci. 2005,11;8(2):289-98.

Carstensen JT, Stremming KP, Pothisiri P. Sedimentation kinetics of flocculated suspensions. 3. Effect of zeta-potential. J Pharm Sci. 1972;61(12):1999-2000.

Dressman JB, Amidon GL, Reppas C, Shah VP. Dissolution testing as a prognostic tool for oral drug absorption: immediate release dosage forms. Pharm Res. 1998;15(1):11-22.

EMA. Guideline on the Investigation of Bioequivalence. C. f. M. P. f. H. Use. Londres, European Medicines Agency; 2010. $27 \mathrm{p}$

FDA. Waiver of In Vivo Bioavailability and Bioequivalence Studies for Immediate-Release Solid Oral Dosage Forms Based on a Biopharmaceutics Classification System. U. S. D. o. H. a. H. Services, F. a. D. Administration and C. f. D. E. a. R. (CDER). Rockville, Food and Drug Administration; 2015. 15p.

Fromm MF. Importance of P-glycoprotein at blood-tissue barriers. Trends Pharmacol Sci. 2004;25(8):423-429.

Gowthamarajan K; Singh, K. S. Dissolution Testing for Poorly Soluble Drugs: A Continuing Perspective. Dissolution Technologies. 2010;24-32.
Graffner C. Regulatory aspects of drug dissolution from a European perspective. Eur J Pharm Sci. 2006;29(3-4):288-293.

ICH. Validation of Analytical Procedures: Text and Methodology Q2 (R1). ICH Harmonized Tripartite Guideline, International Conference of Harmonization of Technical Requirements of Pharmaceuticals for Human Use. 1996.

Kenneth J. Interpreting the Product-Moment Correlation: from Interpreting the Product-Moment Correlation: 2001.

Limberg J, Potthast H. Regulatory status on the role of in vitro dissolution testing in quality control and biopharmaceutics in Europe. Biopharm Drug Dispos. 2013;34(5):247-253.

Oliveira DC, Weich A, Rolim CMB. Simple and reliable HPLC analysis of fexofenadine hydrochloride in tablets and its application to dissolution studies. Pharmazie. 2007; 62(2):96-100.

Rozet E, Ceccato A, Hubert C, Ziemons E, Oprean R, Rudaz S, et al. Analysis of recent pharmaceutical regulatory documents on analytical method validation. J Chromatogr A. 2007;1158(1-2):111-125.

Simons FER, Simons KJ. Histamine and H1-antihistamines: Celebrating a century of progress. J Allergy Clin Immunol. 2011;128(6):1139-1150.e1134.

Soares,T.S.P. Caracterização e estudos de dissolução para hidroclorotiazida suspensão. [dissertação] Ouro Preto: Universidade Federal de Ouro Preto, Escola de Farmácia; 2016.

Sruti J, Patra ChN, Swain SK, Beg S, Palatasingh HR, Dinda $\mathrm{SC}$, Rao ME. Improvement in dissolution rate of cefuroxime axetil by using poloxamer 188 and Neusilin US2. Indian J Pharm Sci. 2007;75(1):67-75.

Türkmen Ö, Ay Şenyiğit Z, Baloğlu E. Formulation and evaluation of fexofenadine hydrochloride orally disintegrating tablets for pediatric use. J Drug Deliv Sci Tec. 2018;43:201-210.

United States Pharmacopea, The United States Pharmacopeial Convention. 2013.

Received for publication on $02^{\text {nd }}$ March 2017 Accepted for publication on $12^{\text {nd }}$ June 2019 